\title{
EVALUASI RENCANA PEMASANGAN SENSOR STRUCTURE HEALTH MONITORING SYSTEM JEMBATAN PULAU BALANG II
}

\author{
Juandra Hartono'), Umi Khoiroh' ${ }^{2)}$ \\ ${ }^{1)}$ Politeknik Pekerjaan Umum, Kementerian Pekerjaan Umum dan Perumahan Rakyat \\ ${ }^{2)}$ Dinas Perhubungan Kota Yogyakarta \\ Email: juandra.hartono@pu.go.id ${ }^{1)}$, umi_khoiroh@yahoo.com ${ }^{2)}$
}

DOI: http://dx.doi.org/10.29103/tj.v11i2.549

(Received: June 2021 / Revised: August 2021 / Accepted: August 2021)

\begin{abstract}
Abstrak
Salah satu isu utama dalam setiap penerapan Structure Health Monitoring System (SHMS) jembatan bentang panjang khususnya jembatan Pulau Balang II adalah bagaimana membuat SHMS tersebut dapat diandalkan secara efektif. Penggunaan sensor yang terlalu banyak tidaklah efisien demi mendapatkan informasi yang selengkap-lengkapnya terkait kondisi jembatan. Tujuan utama riset ini adalah untuk menganalisia tipe sensor, posisi penempatan sensor dan jumlah sensor yang akan dipasang pada SHMS jembatan Pulau Balang sesuai kebutuhan sensor yang efektif dan efisien. Pengamatan SHMS meliputi lendutan dek, pylon serta tegangan dek, pylon. Metode penelitian berupa pengamatan langsung di lapangan, analisa data dan diskusi dengan stakeholder jembatan. Dari hasil analisis terdapat 13 jenis sensor yang sebaiknya dipasang pada SHMS Jembatan Pulau Balang dengan total kebutuhan sensor berjumlah 87 buah. Posisi penempatan sensor sebagian besar ada di pylon, kabel dan dek yang disesuaikan dengan tipe jembatan yaitu cable stayed. Untuk sensor gempa disarankan perlu dipasang hal ini dikarenakan wilayah tersebut memiliki seismistis paling rendah yang didominasi oleh tiga zona sesar utama yaitu sesar mangkalihat, sesar tarakan dan sesar maratus oleh karena itu Kalimantan bukanlah daerah yang bebas gempa bumi.
\end{abstract}

Kata kunci: structural health monitoring system (SHMS), sensor, pylon, dek, cable stayed

\begin{abstract}
One of the main issues in each application of Structure Health Monitoring System (SHMS) in long span bridge particularly Pulau Balang II Bridge is how to make the SHMS effectively dependable. The excessive use of sensors is inefficient in order to obtain complete information regarding the condition of the bridge. The main purpose of this research is to analyze the type of sensor, the position of the sensor placement and the number of sensors that will be installed on the SHMS structure of the Balang Island bridge according to the need for effective and efficient sensors. SHMS observations include deck deflection, pylon and deck stress, pylon. The research method is in the form of direct observation in the field, data analysis and discussions with bridge stakeholders. From the results of the analysis, there are 13 types of sensors that should be installed on the Balang Island Bridge SHMS with a total sensor requirement of 87 units. Most of the sensor placement positions are in the pylons, cables and decks that are adapted to the type of bridge, namely cable stayed. For earthquake sensors, it is recommended to install this because the area has the lowest seismicity which is
\end{abstract}


dominated by three main fault zones, namely the Mangkalihat Fault, Tarakan Fault and Maratus Fault. Therefore, Kalimantan is not an earthquake-free area

Keywords: structural health monitoring system (SHMS), sensor, pylon, deck, cable stayed

\section{Latar Belakang}

Jembatan Pulau Balang II terdapat di Provinsi Kalimantan Timur merupakan salah satu jembatan bentang panjang di Indonesia dengan sistem struktur jembatan tipe Cable Stayed. Jembatan ini memiliki konstruksi yang besar, kompleksitas yang tinggi dan mempunyai nilai strategi yang tinggi, sehingga diperlukan suatu mekanisme yang memungkinkan dapat memudahkan dalam menjaga keberadaan jembatan tersebut agar senantiasa dapat berfungsi dengan baik. Untuk mencapai hal tersebut diperlukan suatu sistem pemantauan (monitoring) secara terus menerus dan berkelanjutan terhadap perilaku kesehatan dan kondisi struktur jembatan selama masa layan.

Monitoring yang dilakukan selama ini masih bersifat visual yang dibantu dengan peralatan sederhana (tangga, alat pengaman, dan lain sebagainya). Mengingat pemeriksaan hanyalah bersifat visual, maka kondisi struktur secara nyata belum diketahui. Disamping itu, tidak semua lokasi dapat diperiksa secara visual sehingga masih banyak lokasi-lokasi yang belum mendapatkan pemeriksaan. Kemungkinan terjadinya kesalahan pemeriksaan juga dimungkinkan mengingat banyaknya bagian yang harus diperiksa serta waktu pemeriksaan yang sangat bergantung pada banyak kondisi dan mengharuskan ditutupnya lalu lintas. Untuk mengantisipasi hal tersebut perlu dilakukan monitoring yang didasarkan kondisi aktual struktur (tegangan, regangan, dan lendutan) serta kondisi lingkungan (kecepatan angin, suhu, kelembaban udara), untuk mendapatkan perilaku struktur sebenamya sehingga dapat diprediksi kondisi keamanan struktur dan sifatnya secara terus menerus (real time). Sistem ini dikenal dengan Structure Health Monitoring System (SHMS) yang sampai saat ini baru dilaksanakan di Jembatan Suramadu (Jawa Timur), Jembatan Merah Putih (Ambon) dan Jembatan Soekarno (Manado). Atas dasar penjelasan di atas, maka dirasa perlu untuk diterapkan SHMS pada jembatan Pulau Balang II (Balai Pelaksanaan Jalan Nasional XII, 2017)

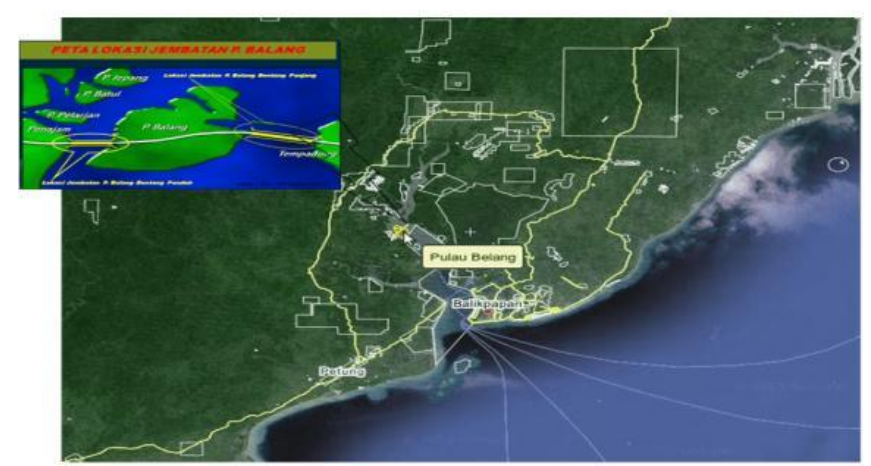

Gambar 1 Lokasi jembatan pulau balang II

Salah satu isu utama dalam setiap penerapan SHMS, khususnya pada struktur jembatan bentang panjang adalah bagaimana membuat SHMS tersebut dapat diandalkan secara efektif. Struktur jembatan bentang panjang memiliki variabel dimensi dan sistem struktural yang kompleks, oleh karena itu tidak praktis untuk 
memprediksi atau mendeteksi kerusakan struktural secara keseluruhan hanya dengan menggunakan satu indeks kerusakan tunggal saja, akan tetapi juga tidaklah efisien menggunakan sensor sebanyak-banyaknya demi mendapatkan informasi yang selengkap-lengkapnya. Penelitian yang dilakukan pakar-pakar SHMS membuktikan bahwa metode pemprosesan data lebih dapat meningkatkan kualitas hasil keluaran SHMS dari sekedar menambah jumlah sensor. Metode yang dimaksud adalah prosedur cerdas yang dapat melakukan simulasi numerik dari data hasil pengukuran sensor menjadi informasi yang dapat digunakan untuk menilai kondisi struktural yang sebenarnya.

Strucural Health Monitoring System adalah suatu sistem yang digunakan untuk memonitor semua hal yang berkaitan dengan operasional serta pemantauan kondisi kesehatan dari suatu struktur, membantu melakukan tindakan koreksi melalui perintah secara manual maupun secara otomatis oleh beberapa peralatan yang ada (Suhendro, 2010). Pemantauan kesehatan struktural (SHMS) dewasa ini menjadi teknologi yang semakin penting untuk menentukan respon statis dan dinamis infrastruktur sipil terhadap kondisi lingkungan atau beban kendaraan selama konstruksi atau dalam pelayanan. Dengan menghitung, membandingkan dan menganalisis, SHMS dapat menjadi sistem peringatan darurat yang dapat memberikan keamanan penilaian untuk keputusan pemeliharaan dan identifikasi kerusakan struktural (Hu, Wang and Ji, 2013). Tujuan utama dari SHMS adalah untuk memantau kondisi pembebanan suatu struktur, untuk menilai kinerjanya di bawah berbagai beban layanan, untuk memverifikasi atau memperbarui aturan yang digunakan dalam tahap desain, untuk mendeteksi kerusakan atau kemerosotannya, dan untuk memandu inspeksi dan pemeliharaannya (Xu and Xia, 2012). Sesuai dengan tujuan pemasangannya, maka ada beberapa pilihan level monitoring yang dapat diambil (Farhey, 2006). Level tersebut tergantung pada parameter-parameter yang akan dimonitor. Level Structural Health Monitoring System (SHMS) diklasifikasikan kedalam 4 kelas, yaitu: kelas 1 dengan kebutuhan penting untuk semua jenis jembatan, kelas 2 dengan kebutuhan perlu untuk optimal Structural Health Monitoring System, kelas 3 dengan kebutuhan perlu untuk minimal maintenance dan kelas 4 dengan kebutuhan baik untuk diketahui. Hasil riset (Fatah, Ungkawa and Barmawi, 2020) menyatakan bahwa untuk meminimalisir kerusakan pada jembatan diperlukan suatu sistem agar bisa memantau kondisi jembatan secara real-time sehingga pemerintah dapat melakukan tindakan sebelum jembatan rusak, seperti membuat sistem informasi pemantauan kondisi jembatan dengan menggunakan Wireless Sensor Network yang terintegrasi dengan Structural Health Monitoring System. Hal yang penting untuk keefektifan sistem monitoring kesehatan struktur adalah pemilihan sensor yang tepat dan tahan lama yang dapat memberikan informasi yang dibutuhkan untuk monitoring dan analisis. Kriteria pemilihan sensor ini dapat ditentukan untuk tiga kategori utama, yaitu karakteristik kinerja sensor, batasan lingkungan, dan pertimbangan ekonomi (Kementerian Pekerjaan Umum dan Perumahan Rakyat, 2015).

Tujuan utama riset ini adalah untuk menganalisis rencana tipe sensor yang akan digunakan, posisi penempatan sensor yang tepat, dan jumlah sensor yang efisien sesuai kondisi struktur jembatan Pulau Balang II. Hasil riset ini dapat digunakan sebagai bahan pertimbangan dalam menentukan pemilihan sensor, lokasi pemasangan sensor dan jumlah sensor yang akan digunakan secara efektif dan efisien. 


\section{Metode Penelitian}

\subsection{Tahapan Penelitian}

Pengamatan rencana pemasangan sensor Structural Health Monitoring System (SHMS) jembatan Pulau Balang terdiri dari beberapa tahapan. Tahapan kegiatan penelitian meliputi:

a) Mengumpulkan informasi penting terkait data struktur jembatan Pulau Balang yang bersumber dari laporan dan gambar perencanaaan.

b) Pengamatan langsung di lapangan berupa pengamatan data jumlah dan data lokasi penempatan sensor yang akan dipasang berdasarkan acuan gambar desain perencanaan teknis (Satker Pelaksanaan Jembatan Pulau Balang, 2017).

c) Koordinasi dengan stakeholder jembatan, terkait efisiensi pemakaian sensor dan posisi pemasangan sensor yang tepat sesuai kebutuhan lapangan.

d) Penentuan jenis sensor sesuai dengan spesifikasi yang akan digunakan (Direktorat Jenderal Bina Marga, 2020).

Dalam evaluasi rencana pemasangan sensor SHMS ini sebagian data-data didapatkan dari laporan akhir pekerjaan perencanaan struktur jembatan Pulau Balang, laporan akhir perencanaan teknis SHMS jembatan, gambar rencana konstruksi jembatan, gambar desain perencanaan teknis SHMS jembatan serta laporan akhir Independent Proof Checker (IPC) jembatan Pulau Balang.

\subsection{Metode Evaluasi}

Evaluasi rencana pemasangan sensor SHMS menggunakan metode pengamatan langsung di lapangan dan analisa data. Jumlah sensor dan posisi penempatan sensor yang bersumber dari laporan akhir perencanaan teknis SHMS jembatan akan dianalisa kembali menggunakan daftar checklist berdasarkan pengamatan langsung di lapangan dan masukan dari stakeholder jembatan. Analisa data menggunakan program midas khususnya di bagian pylon dan dek terkait tegangan dan lendutan bersumber dari laporan Independent Proof Checker (Balai Besar Pelaksanaan Jalan Nasional VII, 2013). Daftar checklist sangat membantu menentukan arah bagaimana menyusun suatu konsep evaluasi SHMS yang efektif dan benar bermanfaat bagi struktur yang diamati. Kriteria yang akan diamati dan dianalisis untuk menentukan kebutuhan dan posisi penempatan sensor yang tepat.

a) Area utama (Key Area) yang akan diamati.

Pada infrastruktur jembatan secara umum cakupan area pengamatan dapat dibagi menurut tipe dari struktur yaitu superstructure yang terdiri dari deck dan pylon, kemudian substructure yang terdiri dari pier dan abutment sesuai SNI 1725-2016 (Badan Standarisasi Nasional, 2016).

b) Parameter apa yang akan diukur.

Diklasifikasikan menurut perilaku/respon dan lokasi pada struktur yang akan diamati seperti stress, gaya dan lendutan.

c) Jenis sensor yang digunakan

Semua jenis sensor yang ada di pasaran pada prinsipnya dapat digunakan, namun akan lebih baik jika sensor tersebut sudah memiliki pengalaman digunakan dalam aplikasi SHMS dan diakui oleh pihak berwenang yang terkait, khususnya untuk struktur jembatan. Jenis sensor yang akan digunakan harus disesuaikan dengan kebutuhan SHMS jembatan Pulau Balang (Balai Pelaksanaan Jalan Nasional XII, 2017). 
Tabel 1 Daftar checklist evaluasi shms jembatan pulau balang II

\begin{tabular}{|c|c|c|}
\hline No & Cheklist Item & Description \\
\hline \multirow[t]{3}{*}{1} & Key Area & Struktur Lantai (Deck) \\
\hline & & Struktur Tiang (Pylon) \\
\hline & & Struktur Kabel (Cable) \\
\hline \multirow[t]{14}{*}{2} & Measured Parameter & Primary: \\
\hline & & Stress Distribution (Deck \& Pylon) \\
\hline & & Deflection (Deck \& Pylon) \\
\hline & & Force (Cable-Stayed) \\
\hline & & Ambient Temperature (Deck \& Pylon) \\
\hline & & Wind velocity (Deck \& Pylon) \\
\hline & & Natural Frequency (Global) \\
\hline & & Seismic (Pylon) \\
\hline & & Secondary: \\
\hline & & Visual \\
\hline & & Corrosion \\
\hline & & Motion \\
\hline & & Special Case: \\
\hline & & Crackmeter \\
\hline \multirow[t]{9}{*}{3} & Candidate Sensor & Tilt / GPS sensor (Deflection) \\
\hline & & Elasto-Magnetic Sensor (Cable Force) \\
\hline & & Temperature Sensor (Ambient Temperature) \\
\hline & & Anemometer (Wind velocity) \\
\hline & & Accelerometer (Ambient Vibration) \\
\hline & & Seismic \& Peak Displacement Sensor (Seismic) \\
\hline & & CCTV (Visual) \\
\hline & & Half Cell / Cathodic Protection (Corrosion) \\
\hline & & WIM Sensor (Motion) \\
\hline 4 & Communication Utilities & --- \\
\hline
\end{tabular}

\subsection{Pemodelan Jembatan Cable Stayed.}

Jembatan cable stayed merupakan suatu sistem struktur statis tidak tentu berderajat tinggi, di mana gaya-gaya dalam yang bekerja dipengaruhi oleh kekakuan komponen utama struktur jembatan, yaitu sistem lantai kendaraan (dek/edge beam/transversal beam) bersama dengan kabel penggantung dan pylon jembatan. Desain jembatan cable stayed memerlukan pemodelan elemen hingga yang akurat untuk prediksi respons terhadap beban, seperti angin, lalu lintas, atau gempa bumi. Aspek ini sangat penting untuk jembatan bentang panjang (Bedon, Dilena and Morassi, 2016). Desain jembatan cable stayed membutuhkan ketelitian yang tinggi terhadap tegangan, fleksibilitas, stabilitas, maupun deformasi jangka pendek dan jangka panjang, berdasarkan analisis statik maupun dinamik yang dihitung pada kondisi awal jembatan maupun pada tahap pelaksanaan. Pemodelan pada jembatan Pulau Balang II adalah pemodelan ulang berdasarkan laporan akhir pekerjaan perencanaan struktur jembatan pulau balang menggunakan program Midas (Balai Besar Pelaksanaan Jalan Nasional VII, 2012).

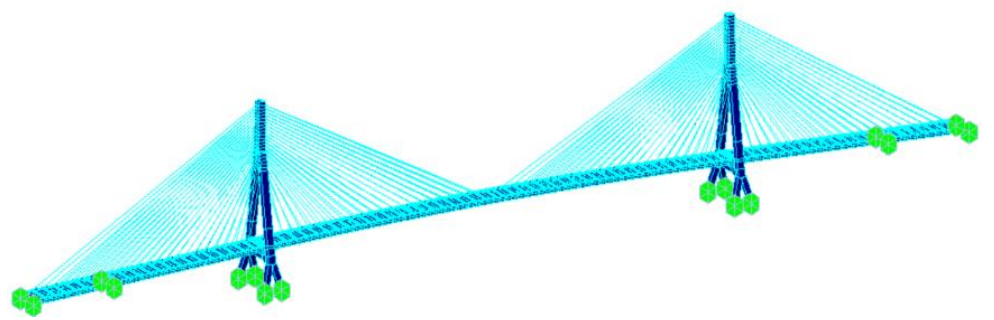

Gambar 2 Pemodelan jembatan pulau balang menggunakan program midas 


\subsection{Rencana Tipe Sensor SHMS Jembatan Pulau Balang}

Rencana sensor yang akan dipasang seperti pada Tabel 2 (Balai Pelaksanaan Jalan Nasional XII, 2017) akan di analisa kembali tujuannya agar pemasangan sensor di lapangan lebih efektif dan efisien.

Tabel 2 Rencana sensor yang dipasang pada SHMS jembatan pulau balang II

\begin{tabular}{cllc}
\hline No & \multicolumn{1}{c}{ Tipe Sensor } & \multicolumn{1}{c}{ Fungsi Sensor } & Jumlah Sensor \\
\hline 1 & Anemometer 2D & Mengukur kecepatan arah angin & 1 \\
\hline & Anemometer 3D & Mengukur kecepatan arah angin & 1 \\
\hline 2 & Em Sensor & Mengukur gaya pada cabel stayed jembatan & 24 \\
\hline 3 & 1-Axis Accelerometer & Mengukur frekuensi natural dan modal shape jembatan & 7 \\
\hline & 2-Axis Accelerometer & Mengukur frekuensi natural dan modal shape jembatan & 8 \\
\hline 4 & Thermometer & Mengukur temperature pada struktur jembatan & 6 \\
\hline 5 & Expansion Joint Meter & Mengukur pergeseran girder terhadap abutment & 20 \\
\hline 6 & Strain Gauge & Mengukur strain struktur jembatan & 1 \\
\hline 7 & 1-Axis Tilt Meter & Mengukur pergerakan pylon & 4 \\
\hline & 2-Axis Tilt Meter & Mengukur pergerakan pylon & 5 \\
\hline 8 & Gps Rover & Mengukur pergerakan pylon dan deck jembatan & 1 \\
\hline & Gps Reference & Mengukur pergerakan pylon dan deck jembatan & 1 \\
\hline 9 & Air Temperature & Mengukur temperatur udara lingkungan & 4 \\
\hline 10 & Rain Gauge & Mengukur curah hujan di area jembatan & 2 \\
\hline 11 & CCTV & Pemantauan visual jembatan & \\
\hline 12 & Warning Light & Sebagai tanda peringatan & \\
\hline
\end{tabular}

\subsection{Kriteria Keamanan}

Kriteria keamanan pada konsep Perencanaan Batas Layan (PBL) ditetapkan dengan menghitung semua tegangan kerja akibat kombinasi pembebanan, yang tidak melampaui tegangan ijin pada kondisi beban tetap maupun beban sementara. Sedangkan kriteria keamanan menggunakan konsep perencanaan berdasarkan beban dan kekuatan terfaktor (PBKT) sesuai SNI T-12-2004 (Badan Standarisasi Nasional, 2004) ditetapkan sesuai persamaan berikut ini :

$$
\emptyset R n \geq \text { dampak dari } \sum y_{i} Q_{i}
$$

di mana $\varnothing$ adalah faktor reduksi kekuatan, $R n$ adalah kekuatan nominal dari penampang komponen struktur, Qi adalah jenis-jenis beban yang berbeda dan $\gamma_{i}$ adalah faktor beban

Analisis komponen struktur beton bertulang pada komponen tiang bor, pile cap, dan pylon pada kondisi tahap selesai konstruksi, dilakukan dengan prinsip Perencanaan berdasarkan Beban dan Kekuatan Terfaktor (PBKT). Kriteria keamanan menggunaakan konsep perencanaan berdasarkan beban dan kekuatan terfaktor (PBKT) sesuai SNI T-12-2004 (Badan Standarisasi Nasional, 2004) ditetapkan sesuai persamaan:

$$
\begin{aligned}
& \mathrm{Mu} \leq \varphi \mathrm{Mn} \\
& \mathrm{Vu} \leq \varphi \mathrm{Vn} \\
& \mathrm{Nu} \leq \varphi \mathrm{Nn}
\end{aligned}
$$

di mana $\mathrm{Mu}$ adalah momen lentur batas (ultimit), $\mathrm{Vu}$ adalah gaya geser batas, $\mathrm{Nu}$ adalah gaya normal batas, Mn adalah momen lentur nominal (kapasitas nominal), Vn adalah gaya geser nominal, $\mathrm{Nn}$ adalah gaya normal nominal dan $\varphi$ adalah faktor reduksi kekuat 


\section{Hasil dan Pembahasan}

\subsection{Data Teknis Jembatan Pulau Balang}

Jembatan Pulau Balang bentang panjang merupakan jembatan tipe cable stayed, yang mempunyai panjang bentang utama 402 meter, dengan panjang total 804 meter, lebar jembatan 22,4 meter yang terdiri dari 4 lajur kendaraan (untuk dua arah) dan 2 lajur trotoar untuk jalan inspeksi. Jumlah kabel penggantung $21+42+$ $21=84$ buah (pada 1 sisi jembatan), yang digantungkan pada 2 menara (pylon) berbentuk "Y" terbalik dengan tinggi 93 meter di atas tumpuan dek jembatan, atau setinggi 112,1 meter di atas permukaan pile cap (Balai Besar Pelaksanaan Jalan Nasional VII, 2012). Detail teknis jembatan dan sketsa model jembatan cable stayed Pulau Balang diperlihatkan pada Tabel 3 dan Gambar 3.

Tabel 3 Data teknis jembatan pulau balang II

\begin{tabular}{cll}
\hline No & \multicolumn{1}{c}{ Data Teknis } & \multicolumn{1}{c}{ Keterangan } \\
\hline 1 & Panjang total jembatan & 804 meter \\
\hline 2 & Bentang utama jembatan & 402 meter \\
\hline 3 & Tinggi ruang bebas navigasi laut & 29 meter (di atas MSL) \\
\hline 4 & Tinggi pylon & 93 meter (diatas tumpuan dek jembatan) \\
\hline 5 & Bentuk Pylon & "Y" terbalik \\
\hline 6 & Jumlah stay cables & $2 \times 2 \times 2 \times$ x 21 stay cable \\
\hline 7 & Konfigurasi stay cables & Tipe kipas \\
\hline 8 & Lebar dek jembatan & 22.4 meter \\
\hline 9 & Jumlah lajur kendaraan & 4 lajur x 3,5 meter (2 arah) \\
\hline 10 & Kemiringan alinyemen memanjang & $3,5 \%$ (maksimum) \\
\hline
\end{tabular}

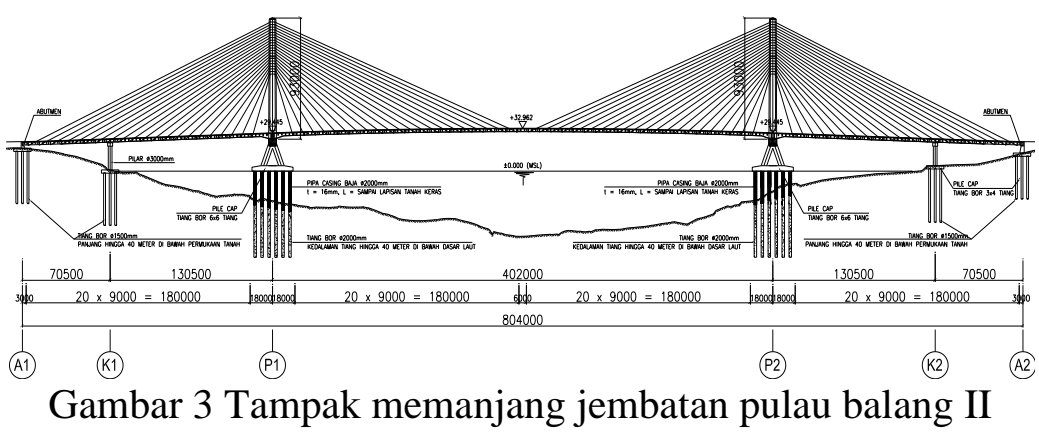

\subsection{Struktur dan Perilaku Gaya Jembatan Pulau Balang II}

Tegangan ijin beton prategang untuk struktur atas jembatan berdasarkan SNI T-12-2004 standar perencanaan struktur beton untuk jembatan terdiri dari 2 tahap, data diambil dari (Balai Besar Pelaksanaan Jalan Nasional VII, 2012) :

Pada saat transfer, Aksial dan lentur tekan sebesar 21,6 Mpa, Lentur tarik sebesar 1,5 Mpa dengan Asumsi: $f c i$ 'sebesar 0,80 fc'. Pada kondisi layan Aksial dan lentur tekan sebesar 20.25 Mpa, Lentur tarik sebesar 3,35 Mpa. Kabel penggantung (stay cables), Epoxy coated 7 wire strand dengan diameter 0,6" $(15,2 \mathrm{~mm})$ dan jenis relaksasi rendah (low relaxation), Tegangan putus ultimate fpu sebesar $1860 \mathrm{Mpa}$ dan Tegangan leleh minimum fpy sebesar $1580 \mathrm{Mpa}$.

\subsubsection{Tegangan pada Pylon pada saat konstruksi}

Hasil analisa tegangan pylon pada jembatan diperlihatkan pada Gambar 3, Hasil analisa menggunakan program midas 2013. Berdasarkan Gambar 3 didapatkan nilai tegangan serat bawah tekan sebesar -11.3 MPa dan tarik sebesar 2.19 Mpa. Untuk nilai serat atas tekan 10.9 MPa dan tarik 1.046 Mpa. Hasil 
pembacaan tegangan melalui program midas dibandingkan dengan tegangan ijin beton prategang. Dari hasil perhitungan didapatkan tegangan izin aksial dan lentur tekan sebesar 20,25 Mpa sedangkan untuk lentur tarik sebesar 3,35 Mpa.

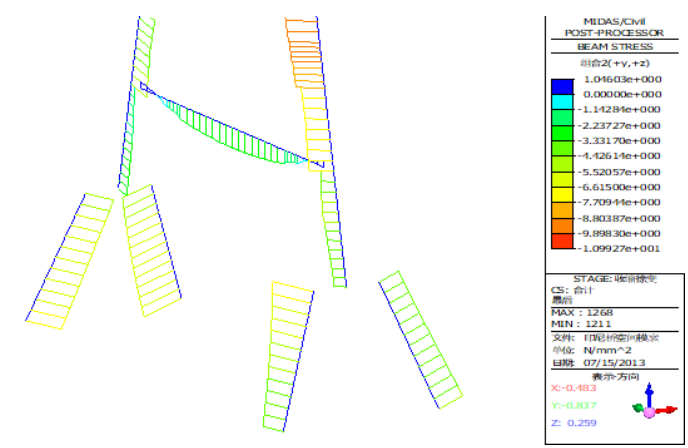

Gambar 4 Tegangan saat konstruksi pada pylon serat atas dan bawah

Dari hasil pembacaan Gambar 4 terlihat bahwa tegangan yang terjadi lebih kecil dari tegangan izin sesuai dengan syarat SNI T-12-2004 (Badan Standarisasi Nasional, 2004). Tarik terbesar di daerah balok penyangga dek bagian bawah, tekan maksimum berada pada pylon tepat di bawah dek dan di pylon atas dek tepat pada bagian lubang pylon membesar di atas pintu masuk pylon.

\subsubsection{Lendutan pada Pylon}

Data yang didapat dari laporan akhir pekerjaan perencanaan struktur pembangunan jembatan Pulau Balang (Balai Besar Pelaksanaan Jalan Nasional VII, 2012) berupa tinggi struktur (H) sebesar $116000 \mathrm{~mm}$, lendutan beban mati sebesar $104 \mathrm{~mm}$, lendutan beban hidup sebesar $106 \mathrm{~mm}$ dan lendutan total sebesar $211 \mathrm{~mm}$. Pemodelan hasil program midas diperlihatkan pada Gambar 5.

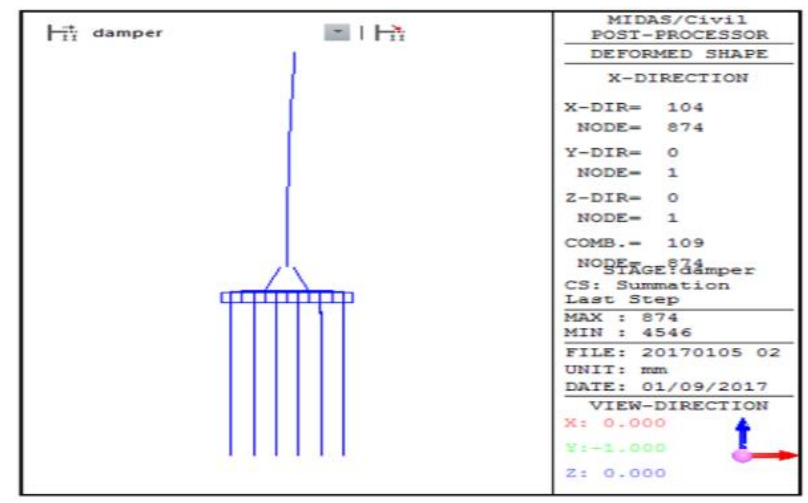

Gambar 5 Lendutan pada pylon akibat beban mati total (mm)

Dari Gambar 5 diatas didapat nilai lendutan beban mati sebesar $104 \mathrm{~mm}$ dan maksimum lendutan total ke arah longitudinal sebesar $211.4 \mathrm{~mm}$ ke arah longitudinal (Balai Pelaksanaan Jalan Nasional XII, 2017) . Untuk ambang batas (tresshold) tidak ada peraturan jembatan untuk lendutan pada pylon, jadi ambang batas yang digunakan untuk lendutan pylon menggunakan H/600 dari As Built untuk beban transien dari as pier sesuai gambar desain perencanaan teknis SHMS jembatan Pulau Balang II (Satker Pelaksanaan Jembatan Pulau Balang, 2017) didapat ambang batas lendutan sebesar 193,33 mm. 


\subsubsection{Tegangan pada dek}

Dari hasil pembacaan didapat hasil maximum stress (serat atas $+\mathrm{z}$ ) nilai tekan sebesar -12.98 MPa dan tarik sebesar 1,51 Mpa. Tekan maksimum terjadi pada ujung pier table. Tarik terjadi pada ujung saat belum menyentuh abutmen A1 A2. Dari hasil pembacaan tegangan maksimum pada gambar 5 terlihat bahwa tegangan yang terjadi < tegangan izin sesuai syarat SNI T-12-2004 (Badan Standarisasi Nasional, 2004) yaitu sebesar 20,35 Mpa untuk tekan dan 3,35 Mpa untuk tarik.

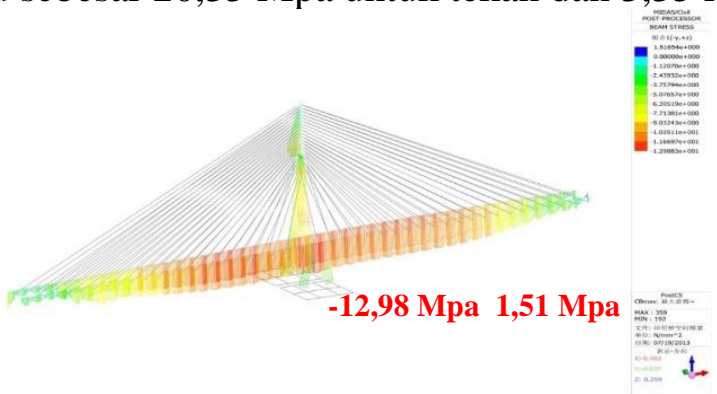

Gambar 6 Tegangan maksimum single cantilever jembatan pada tahap konstruksi

\subsubsection{Lendutan pada dek}

Berdasarkan gambar desain SHMS jembatan Pulau Balang (Satker Pelaksanaan Jembatan Pulau Balang, 2017) didapat nilai lendutan maksimum sebesar 423,6 mm di tengah bentang ke bawah dan $90.5 \mathrm{~mm}$ keatas. Dari hasil perhitungan ambang batas (tresshold) sesuai SNI T-12-2004 (Badan Standarisasi Nasional, 2004) dan SNI 1725-2016 (Badan Standarisasi Nasional, 2016) digunakan L/800 mm untuk beban hidup 402/800 didapat lendutan maksimum 502 $\mathrm{mm}$. Hasil pembacaan lendutan menggunakan program midas didapat lendutan < lendutan izin $423,6 \mathrm{~mm}<502 \mathrm{~mm}$.

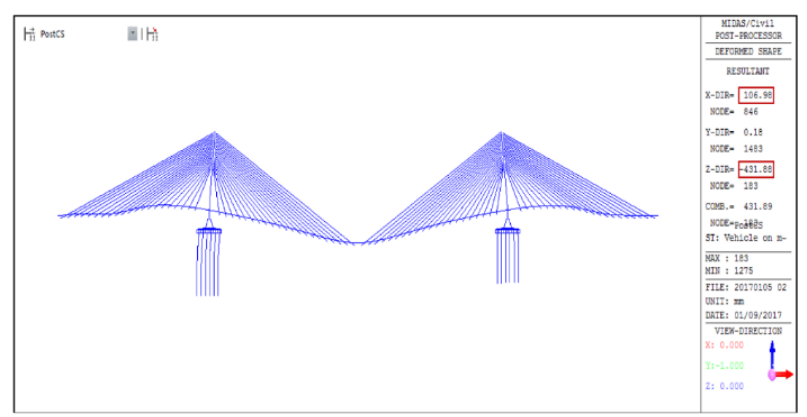

Gambar 7 Lendutan pada penampang dek jembatan akibat beban kendaraan

Gaya pada kabel, pylon dan dek serta lendutan pada pylon dan dek memegang peranan penting pada struktur jembatan tipe cable stayed. Untuk pemilihan sensor, harus dipastikan sensor yang dipasang pada dek bisa membaca lendutan di tengah bentang dan displacement di puncak pylon. Apabila sensor diletakkan pada pylon dan pylon bergerak sehingga menyebabkan deformasi rotasi yang kecil, maka bisa menyebabkan eror yang besar, hal tersebut merupakan parameter utama untuk mengetahui kesehatan jembatan, disamping itu karakteristik getaran atau perilaku dinamis diyakini sebagai sidik jari dari struktur jembatan karena tidak hanya menjelaskakn kekakuan total seperti kondisi awal struktur tetapi juga menjelaskan banyak masalah pada struktural lainnya (Zhang, Zhang and Ficher, 2007) 


\subsection{Jenis Sensor Yang Akan Digunakan}

Berdasarkan hasil pengamatan lapangan, hasil diskusi dengan narasumber SHMS jembatan Pulau Balang, hasil analisa jembatan yang bersumber dari laporan akhir Independent Proof Checker (IPC) jembatan serta hasil pemodelan midas, berikut saran terhadap pemilihan sensor dan lokasi penempatan sensor yang akan digunakan pada SHMS Jembatan Pulang Balang II.

a) Anemometer, menurut Wind Resistance Design Spesification for Highway Bridges, koefisien $\mu \mathrm{f}$, mengingat pengaruh turbulensi pada kecepatan angin dan korelasi angin yang tidak lengkap sepanjang span jembatan ditetapkan koefisien $\mu \mathrm{f}$ sebesar 1,24. Panjang main span jembatan 402, mengingat ketidakpastian dalam Wind Tunnel, desain dan konstuksi jembatan ditetapkan nilai faktor keamanan (K) sebesar 1,2 (Balai Besar Pelaksanaan Jalan Nasional VII, 2012). Referensi desain kecepatan angin ditingkat dek untuk keadaan servis (Ud) sebesar 40,39 m/s, dengan demikian flutter yang mengecek kecepatan angin untuk keadaan servis dengan return period 100 tahun dapat ditentukan Ucr $=\mathrm{k} . \mu \mathrm{f} . \mathrm{Ud}=1,2 \times 1,24 \times 40,39=60,1 \mathrm{~m} / \mathrm{s}$

Sensor anemometer-2D pada struktur jembatan dipasang di ujung atas pylon sebanyak 1 buah dan sensor anemometer-3D dipasang di tengah dek jembatan sebanyak 1 buah. anemometer pada pylon diletakkan 5 meter dari puncak pylon tertinggi sedangkan pada dek dipasang 5 meter dari tepi terluar jembatan sesuai pedoman SHMS jembatan bentang panjang (Direktorat Jenderal Bina Marga, 2013). Fungsi alat anemometer untuk mengukur kecepatan dan arah angin. Alat dipasang selama konstruksi untuk menujukkan nilai flatter jembatan sebagai peringatan sebelum maksimal nilai flatter yang telah dihitung. Nilai flatter jembatan sebesar $60 \mathrm{~m} / \mathrm{s}$, alat yang digunakan nantinya akan mengikuti spesifikasi Wind Speed 0-60 m/s (Satker Pelaksanaan Jembatan Pulau Balang, 2017). Anemometer yang dipasang digunakan untuk mengukur kecepatan angin maksimal, sedangkan penempatan pada deck berguna untuk mengukur uplift pada jembatan dan kecepetan angin bagi pengguna jalan.

b) Em Sensor, memiliki fungsi untuk mengukur gaya pada kabel di jembatan secara real time. Jika kabel terlalu tegang maka kabel tersebut dapat putus (Sutandi, AC.,Pratama, 2011). Em Sensor di letakkan pada kabel yang memiliki gaya paling besar (Direktorat Jenderal Bina Marga, 2013). Em Sensor dapat diletakkan di dalam sehingga harus dilaksanakan pada waktu konstruksi. Sensor elektromagnetik yang akan dipasang pada jembatan berjumlah 24 buah, masing-masing dipasang pada sisi hulu sebanyak 12 buah dan sisi hilir sebanyak 12 buah. Apabila terdapat kabel yang bermasalah maka kabel terdekat yang dipasang sensor elektromagnetik akan memberikan isyarat yang ditandai dengan nilai kabel tegangan yang tiba-tiba membesar. Pemilihan tipe EM sensor didasarkan pada spesifikasi yang telah ditentukan yaitu tegangan yang diijinkan sebesar $240 \mathrm{kN}$ dan beban ultimit sebesar $640 \mathrm{kN}$ (Satker Pelaksanaan Jembatan Pulau Balang, 2017).

c) Accelorometer 2-Axis yang akan dipasang berjumlah 7 buah diletakkan pada dek jembatan sebanyak 5 buah dan pada kabel sebanyak 2 buah. Alat accelerometer digunakan saat masa service jembatan. Accelerometer berguna untuk mengukur frekuensi natural dan modal shape pada jembatan. Accelerometer 2-Axis pada kabel digunakan untuk mengecek tegangan dari frekuensi sebagai data sekunder terhadap EM sensor. Pada Dek untuk 
memberikan gambaran getaran yang terjadi, umumnya frekuensi getaran yang terjadi adalah $0-1 \mathrm{~Hz}$, sedangkan pada kabel frekuensi yang terjadi adaah 0 $60 \mathrm{~Hz}$ (Balai Pelaksanaan Jalan Nasional XII, 2017). Alat yang digunakan pada struktur memiliki spesifikasi pembacaan frekuensi hingga $10 \mathrm{~Hz}$, untuk kabel hingga $1000 \mathrm{~Hz}$ (Direktorat Jenderal Bina Marga, 2020)

d) Air thermometer dan thermometer yang akan dipasang berjumlah 8 buah. 4 buah sensor dipasang pada dek tepatnya di tengah dan seperempat bentang, 4 buah sensor selanjutnya dipasang pada bagian bawah pylon. Air thermometer berguna untuk mengukur suhu udara di lingkungan sekitar sedangkan thermometer berguna untuk suhu pada struktur jembatan. Alat sensor ini diperlukan untuk mengetahui suhu karena struktur jembatan berpengaruh pada suhu sekitar. Air thermometer dan thermometer dipasang saat konstruksi berlangsung. Untuk air thermometer, saat konstruksi dipasang pada seperempat bentang jembatan, dan saat service alat dipindahkan ke tengah bentang jembatan. Pemilihan tipe thermometer didasarkan kepada spesifikasi yang telah ditentukan yaitu suhu operasional berkisar antara $0-65^{\circ}$ (Satker Pelaksanaan Jembatan Pulau Balang, 2017)

e) Expansion Joint Meter, berguna untuk mengukur displacement/pergerakan pada girder terhadap abutment. Expansion Joint Meter yang digunakan berjumlah 6 buah. Masing-masing sensor diletakkan 2 buah pada Pier, 2 buah pada abutmant dan 2 buah pada pylon. Joint meter diperlukan saat masa service jembatan, karena jembatan Pulau Balang II merupakan salah satu jembatan bentang panjang, getaran yang terjadi saat jembatan dilewati beban berat, badan lintasan akan bergerak dan dapat mengakibatkan pergeseran jembatan. Joint meter akan memberikan parameter nilai displacement yang terjadi, sehingga alat ini dibutuhkan pada jembatan untuk mengetahui pergeseran yang terjadi akibat getaran yang berlebih. Ambang batas (tresshold) maksimum di ujung expansoin joint meter sebesar $175 \mathrm{~mm}$ untuk kategori peringatan dan 560 mm untuk kondisi bahaya (Satker Pelaksanaan Jembatan Pulau Balang, 2017)

f) Strain gauge, dipasang saat konstruksi dan tetap terpasang selama masa service jembatan. Jumlah pemasangan starin gauge sebanyak 20 buah, masing-masing dipasang pada dek jembatan sebanyak 12 buah dan pada pylon sebanyak 8 buah. Strain gauge berfungsi untuk mengukur strain pada struktur jembatan sehingga ketika struktur jembatan terjadi pembebanan, maka struktur akan terjadi strain, data tersebut nantinya akan ditrasmisikan ke alat agar data strain dapat terbaca untuk kemudian selanjutnya diolah. Strain gauge diletakan di daerah yang terjadi momen positif pada daerah pylon dan dek jembatan. Batas bacaan alat yang diperlukan minimal adalah 1000. alat yang digunakan nantinya memiliki spesifikasi pembacaan hingga 3000 (Direktorat Jenderal Bina Marga, 2020).

g) Tilt Meter, berfungsi untuk membaca pergerakan pada pylon. Pemasangan sensor Tilt Meter 1-Axis sebanyak 1 buah, lokasi pemasangan pada dek-mid span sedangkan untuk Tilt Meter 2-Axis akan dipasang 2 buah pada pile cap dan 2 buah pada pylon. Pada pylon, Tilt meter diletakkan di ujung pylon dan bagian bawah pylon. Derajat pembacaan pada Tilt meter yang digunakan adalah $1^{\circ}$ dengan ketelitian hingga $0.0001 \mathrm{~mm}$ (Direktorat Jenderal Bina Marga, 2020). 
h) GPS, berfungsi untuk mengukur pergerakan/displacement pada pylon dan dek jembatan. Pada jembatan, saat konstruksi akan terjadi pergerakan pada pylon dan deck dikarenakan pembebanan. Untuk mengukur pergerakan tersebut perlu dipasang perangkat GPS. Perangkat GPS yang dipasang saat konstruksi tidak akan dilepas dan tetap terpasang selama masa service jembatan. Pada struktur jembatan sensor GPS Rover dipasang sebanyak 5 buah 3 buah pada dek dan 2 buah pada pylon. Untuk GPS Reverence kebutuhan sensor 1 buah yang akan diletakkan pada ruang monitoring. GPS Rover diletakaan di jembatan untuk mengukur displacement terhadap GPS Reference yang diletakkan di Gedung Monitoring (Balai Pelaksanaan Jalan Nasional XII, 2017).

i) Rain Gauge, berguna untuk mengukur curah hujan dalam kurun waktu tertentu (sekitar satu minggu). Alat ini akan memberikan data curah hujan dengan melihat grafik yang ada pada tabung skala. Pada jembatan sensor Rain Gauge akan dipasang sebanyak 1 buah yang akan diletakkan pada dek-mid span.

j) CCTV, berfungsi untuk memonitor pergerakan yang ada di jembatan baik itu lalu lintas kendaraan, lalu lintas kapal dan pergerakan manusia serta benda lainnya yang melewati di atas dek jembatan atau di bawah jembatan pada jalur pelayaran. CCTV akan dipasang sebanyak 4 buah dan diletakkan pada pylon P1 dan pylon P2 (Satker Pelaksanaan Jembatan Pulau Balang, 2017).

k) Sensor Warning Light, berfungsi sebagai tanda peringatan sebanyak 2 buah, lokasi alat diletakkan di awal masuk jembatan arah sisi hilir dan awal masuk jembatan sisi hulu (Balai Pelaksanaan Jalan Nasional XII, 2017)

1) Sensor gempa, disarankan dipasang pada SHMS jembatan hal ini dikarenakan di daerah tersebut memiliki seismistis paling rendah dan didominasi oleh aktivitas sesar, oleh sebab itu Kalimantan bukanlah daerah yang bebas gempa bumi karena teridentifikasi tiga zona sesar utama, yaitu sesar mangkalihat, sesar tarakan dan sesar maratus (Siahaan and Andayani, 2021).

\subsection{Posisi dan Jumlah Sensor Yang Dibutuhkan Pada SHMS Jembatan}

Dari hasil analisa, pengamatan lapangan dan diskusi dengan stakeholder jembatan didapat jenis sensor, jumlah sensor dan posisi penempatan sensor yang efisien untuk SHMS Jembatan Pulau Balang II.

Tabel 4 Hasil analisa kebutuhan sensor yang SHMS jembatan

\begin{tabular}{llcl}
\hline No & \multicolumn{1}{c}{ Tipe Sensor } & $\begin{array}{c}\text { Jumlah } \\
\text { Sensor } \\
\text { (buah) }\end{array}$ & \multicolumn{1}{c}{ Posisi Penempatan } \\
\hline 1 & Anemometer 2D & 1 & Puncak pylon-P1 \\
\hline & Anemometer 3D & 1 & Deck-Mid span \\
\hline 2 & Em Sensor & 24 & Kabel \\
\hline 3 & 2-Axis Accelerometer & 7 & Kabel, Deck-Mid Span, Dek Side Span \\
\hline 4 & Thermometer & 8 & Deck-Mid Span, Pylon P1 \\
\hline 5 & Expansion Joint Meter & 6 & Pier, Abutman, Pylon \\
\hline 6 & Strain Gauge & 20 & Deck-Mid Span, Dek-Side Span, \\
& & & Pylon-P1 dan Pylon P2 \\
\hline 7 & 1-Axis Tilt Meter & 1 & Deck-Mid Span, \\
\hline & 2-Axis Tilt Meter & 4 & Pylon dan Pile Cap \\
\hline 8 & Gps Rover & 5 & Pylon, Dek \\
\hline & Gps Reference & 1 & Gedung Monitoring \\
\hline 9 & Air Temperature & 1 & Deck-Mid Span \\
\hline 10 & Rain Gauge & 1 & Deck-Mid Span \\
\hline
\end{tabular}




\begin{tabular}{llll}
\hline 11 & CCTV & 4 & Pylon-P1 dan Pylon-P2 \\
\hline 12 & Warning Light & 2 & $\begin{array}{l}\text { Ujung Jembatan arah pulau balang sisi } \\
\text { hilir dan sisi hulu }\end{array}$ \\
\hline 13 & Seismic Sensor & 1 & pylon \\
\hline
\end{tabular}

\section{Kesimpulan dan Saran}

\subsection{Kesimpulan}

Terdapat 13 jenis sensor yang sebaiknya dipasang pada struktur jembatan Pulau Balang II dengan total keseluruhan sensor berjumlah 87 buah. Posisi penempatan sensor hampir sebagian besar ada di Pylon, kabel dan dek sesuai prioritas pemasangan sensor untuk jembatan tipe cable stayed. Sensor gempa disarankan perlu dipasang pada SHMS jembatan Pulau Balang, hal ini dikarenakan di daerah tersebut memiliki seismistis paling rendah dan didominasi oleh aktivitas sesar, oleh sebab itu Kalimantan bukanlah daerah yang bebas gempa bumi

\subsection{Saran}

Output dari Structure Health Monitoring System (SHMS) Jembatan Pulau Balang II diharapkan tidak sebatas hanya menampilkan data saja tetapi harus sampai pada arah kebijakan. Hasil dari SHMS tersebut harus sampai pada level kesimpulan yang menyatakan bahwa jembatan itu sehat atau jembatan tersebut perlu diperiksa. Alangkah baiknya sebelum dipasang permanen, dilakukan observasi dahulu pada lokasi rencana (data-sampling) untuk mendapatkan contoh hasil yang selanjutnya digunakan sebagai bahan studi lebih lanjut dalam menentukan lokasi pemasangan sensor yang efektif.

\section{Ucapan Terima Kasih}

Ucapan terimakasih kepada semua pihak yang telah membantu dalam penelitian ini, terutama Balai Pelaksanaan Jalan Nasional XII dan Satker Pelaksanaan Jembatan Pulau Balang II yang telah membantu terlaksananya penelitian ini.

\section{Daftar Kepustakaan}

Badan Standarisasi Nasional, 2004. Perencanaan Struktur Beton Untuk Jembatan. Indonesia. BSN, Jakarta

Badan Standarisasi Nasional, 2016. Standar Pembebanan untuk Jembatan. BSN, Jakarta

Balai Besar Pelaksanaan Jalan Nasional VII, 2012. Laporan Akhir Perencanaan Struktur Jembatan Pulau Balang Bentang Panjang. Banjarmasin.

Balai Besar Pelaksanaan Jalan Nasional VII, 2013. Laporan Akhir Independent Proof Checker (IPC) Jembatan Pulau Balang II. Banjarmasin.

Balai Pelaksanaan Jalan Nasional XII, 2017. Laporan Akhir Perencanaan Teknis Strukture Health Monitoring System Jembatan Pulau Balang. Banjarmasin. 
Bedon, C., Dilena, M. and Morassi, A, 2016. Ambient vibration testing and structural identification of a cable-stayed bridge. Meccanica, 51(11), pp. 2777-2796. doi: 10.1007/s11012-016-0430-2.

Direktorat Jenderal Bina Marga, 2013. Pedoman SHMS Sederhana Pada Konstruksi Jembatan Bentang Panjang. Jakarta, Indonesia.

Direktorat Jenderal Bina Marga, 2020. Direktorat Jenderal Bina Marga. Indonesia.

Farhey, D, 2006. Integrated Virtual Instrumentation and Wireless Monitoring for Infrastructure Diagnostics. Structural Health Monitoring Journal, 5(29), pp. 129-143. Available at: https://journals.sagepub.com/doi/abs/10.1177/ 1475921706057980.

Fatah, A., Ungkawa, U. and Barmawi, M. M, 2020. Implementasi Algoritma Fast Fourier Transform Pada Monitor Getaran Untuk Analisis Kesehatan Jembatan. Infotronik: Jurnal Teknologi Informasi dan Elektronika, 5(2), p. 48. doi: 10.32897/infotronik.2020.5.2.414.

Hu, X., Wang, B. and Ji, H, 2013. A Wireless Sensor Network-Based Structural Health Monitoring System for Highway Bridges. Computer-Aided Civil and Infrastructure Engineering, 28(3), pp. 193-209. doi: 10.1111/j.14678667.2012.00781.x.

Kementerian Pekerjaan Umum dan Perumahan Rakyat, 2015. Perencanaan Sistem Monitoring Kesehatan Struktur Jembatan. PUPR, Jakarta

Satker Pelaksanaan Jembatan Pulau Balang, 2017. Gambar Desain Perencanaan Teknis Structure Health Monitoring System (SHMS) Jembatan Pulau Balang II. Balikpapan.

Siahaan, Y. S. B. and Andayani, R, 2021. Analisis Pengaruh Konfigurasi Menara Pada Jembatan Cable Stayed Akibat Beban Gempa. Jurnal Rekayasa Sipil (JRS-Unand), 17(1), p. 37. doi: 10.25077/jrs.17.1.37-51.2021.

Suhendro, B, 2010. SHMS Jembatan Suramadu Sebagai Penunjang Preservasi Dan Pengembangan Teknologi Jembatan. in Prosiding dari Diskusi Sistem Monitoring Kesehatan Struktur Untuk Menunjang Pemeliharaan Jembatan Suramadu dan Pengembangan Teknologi Jembatan yang Berkelanjutan di Indonesia. Surabaya.

Sutandi, AC.,Pratama, B, 2011. Evaluasi Awal Pemasangan Structural Health Monitoring System Pada Jembatan Suramadu. Prosiding Seminar Nasional Transportasi yang Berkelanjutan, p. T-63.

$\mathrm{Xu}, \mathrm{Y}$. L. and Xia, Y, 2012. Structural health monitoring of long-span suspension bridges, Structural Health Monitoring of Long-Span Suspension Bridges. doi: $10.1201 / \mathrm{b} 13182$.

Zhang, G., Zhang, Z. and Ficher, C, 2007. Structural health monitoring of a longspan cable-stayed bridge. Journal of Intelligent Material Systems and Structures, 18(8), pp. 835-843. doi: 10.1177/1045389X06074568. 